\title{
ADSORPTION OF BENZENE AND PYRIDINE VAPORS BY VARIOUS CARBON ADSORBENTS
}

\author{
Oksana V. Belyaeva*, Tamara A. Krasnova
}

Kemerovo Institute of Food Science and Technology (University), Stroiteley blvd. 47, Kemerovo, 650056 Russian Federation

Received April 28, 2016;

* e-mail: ecolog1528@yandex.ru

Accepted in revised form June 18, 2016;

Published June 30, 2016

\begin{abstract}
For the first time with the help of express-method we compare adsorption of benzene and pyridine vapors by carbon adsorbents (CA) that differ in raw materials, methods of production and textural characteristics. With the BET and Aranovich (AR) equations we define the interval of relative pressure, in which the adsorption of studied components is described by suggested models of polymolecular adsorption, and calculated general characteristics of adsorption. A comparative analysis of these equations shows that adsorption isotherms of benzene vapors should be described with the Aranocich model and pyridine vapors with the BET model. It is stated that the adsorption of both benzene and pyridine is characterized by the low energy constant $\mathrm{C}$ that means weak adsorption localization on a carbon surface and difficulty with exact determination of monolayer capacity. We stated that with benzene adsorption by CA and pyridine adsorption by lignite sorbent the area taken by adsorbate molecule exceeds molecule's own size. Such action is typical for realized specific sorbent-sorbate interaction which is expected by molecular structure of adsorbates and surface state of adsorbents and is proved by the amount of calculated adsorption heat. It is stated that pyridine molecules when adsorbed are oriented in parallel to the adsorbent surface and for benzene molecules such reaction exists only for granular carbon adsorbents. Random orientation of benzene molecules when adsorbed by granular CA can be connected with overall attraction-repulsion effect of $\pi$-electron system of benzene and polar groups on the adsorbent surface. We define the exponent of the Dubinin-Astakhov equation using the theory of volume filling of micropores (TVFM), calculate the limiting adsorption volume and size of pores occupied by components. We state that both benzene and pyridine adsorption proceeds similarly in available at size micro- and mesopores of adsorbents. Differences in adsorption behavior of benzene and pyridine with a filled monolayer are probably connected with peculiarities of molecule structure of pyridine which has an additional potential center of adsorption that is an unshared electron pair of nitrogen.
\end{abstract}

Keywords: vapor adsorption, carbon adsorbents, pyridine, benzene

\section{INTRODUCTION}

Isotherms of adsorption-desorption of vapors and gases allow to estimate characteristics of adsorbent structure. To define monolayer specific surface and capacity we traditionally use the BET polymolecular adsorption theory that describes the process of sorbentsorbate interaction with the help of the following equation [1]:

$$
a=a_{m} \frac{C \cdot X}{(1-X) \cdot[1+(C-1) \cdot X]},
$$

where is an equilibrium vapor adsorption; $a_{m}$ is a capacity of a filled monolayer; $X$ is a relative pressure $\left(\mathrm{P} / \mathrm{P}_{0}\right) ; C$ is a constant of an adsorbent-adsorbate interaction. But there are some restrictions to this equation, among them are narrow relative pressure range $\left(0.05<\mathrm{P} / \mathrm{P}_{0}<0.35\right)$ of linear dependence observance, absence of surface heterogeneity and specific sorbent-sorbate interaction $[1,2]$.

Some drawbacks of the BET theory were taken into account in the Aranovich model $[2,3]$ whose equation (thermodynamically more correct) allows to describe isotherms within the range of relative pressures up to $0.7-0.8[2,3]$ :

$$
a=a_{m} \frac{C \cdot X}{(1-X)^{0.5} \cdot(1+C \cdot X)} .
$$

These equations were derived for the case of gase adsorption on nonporous adsorbents that is why if an adsorbent has a big number of micropores then calculated values of the total surface area can greatly differ from the real value [2] that is why this parameter can be estimated only conditionally.

For studies on characteristics of porous structure of adsorbents most frequently as an adsorbate nitrogen is used for which we can clearly differentiate processes of monolayer filling and the following polymolecular layer formation [2]. But in the case of the following sorbent usage for adsorption of aromatic organic compounds it is better to use benzene as a test adsorbate because its conditions of adsorption and molecule size are close to practical problems [4].

Please cite this article in press as: Belyaeva O.V., Krasnova T.A. Adsorption of benzene and pyridine vapors by various carbon adsorbents. Science Evolution, 2016, vol. 1, no. 1, pp. 3-7.

Copyright (C) 2016, KemSU. This is an open access article distributed under the terms of the Creative Commons Attribution 4.0 International License (http://creativecommons.org/licenses/by/4.0/), allowing third parties to copy and redistribute the material in any medium or format and to remix, transform, and build upon the material for any purpose, even commercially, provided the original work is properly cited and states its license. This article is published with open access at http://science-evolution.ru/. 
To estimate porosity we use the DubininRadushkevich equation (the model of TVFM) or its modified versions (the Dubinin-Astakhov equation, the Dubinin-Stoekli equation and others) $[3,5]$ :

$$
a=\frac{W_{0}}{V_{M}} \exp \left[-\left(\frac{R T}{\beta E} \ln \frac{1}{X}\right)^{2}\right],
$$

where $\mathrm{X}$ is a relative pressure; $V_{M}$ is a molar volume, $\mathrm{cm}^{3} / \mathrm{mole} ; W_{0}$ is a limiting volume of adsorption space, $\mathrm{cm}^{3} / \mathrm{g}$; $\mathrm{E}$ is characteristic energy of adsorption, $\mathrm{J} / \mathrm{mole}$; $\beta$ is an affinity coefficient.

The aim of this research is to study adsorption of benzene and pyridine vapors by carbon materials that differ in raw material, method of production and characteristics of porous structure, to choose an equation of polymolecular adsorption describing adsorption equilibrium, to calculate general parameters of adsorption of organic compounds with the usage of polymolecular adsorption models and the theory of volume filling of micropores.

\section{MATERIALS AND METHODS}

Used benzene and pyridine were purified according to the method in [6].

Activated charcoal of brands AG-OV-1 and AG-5 (OJSC "Sorbent", Perm) and activated semi-coke of brands Purolat-Standart (LLC "Ters", Shakhty) and ABG (CJSC "Carbonika F”, Krasnoyarsk) were used as adsorbents. Basic characteristics of adsorbents are given in Table 1.

$$
Y_{D A}=\ln a=\ln \left(W_{0} / V_{M}\right)-D[\ln (1 / X)]^{n},
$$

where $\mathrm{D}=(\mathrm{RT} / \beta \mathrm{E})^{\mathrm{n}}$.

Adsorption heat of the first adsorbate layer $(\Delta \mathrm{Q})$ was calculated by the formula (4) for the BET model and (5) for the Aranovich model:

$$
\begin{gathered}
\Delta Q=R T \ln C, \\
\Delta Q=R T \ln \left(C \rho_{l} / \rho_{v}+1\right),
\end{gathered}
$$

where $\rho_{\mathrm{l}}$ and $\rho_{\mathrm{v}}$ are densities of liquid adsorbate and its saturated vapor accordingly, $\mathrm{g} / \mathrm{cm}^{3}$.

Average area occupied by adsorbate molecule in a filled monolayer $\left(\omega_{\mathrm{m}}, \mathrm{nm}^{2}\right)$ was calculated by

$$
\omega_{m}=\frac{\mathrm{S}_{\mathrm{BET}}}{\mathrm{a}_{\mathrm{m}} \mathrm{N}_{\mathrm{A}}},
$$

where $\mathrm{S}_{\mathrm{BET}}$ is a surface area of activated charcoal, $\mathrm{m}^{2} / \mathrm{g} ; \mathrm{a}_{\mathrm{m}}$ is an adsorption capacity of a saturated monolayer, mole $/ \mathrm{g}, \mathrm{N}_{\mathrm{A}}$ is Avogadro's number.

Half-width of slit-shaped micropores $(\chi, \mathrm{nm})$ occupied by a component was calculated with the usage of dependence [2]:

$$
\chi=\frac{12 \cdot 10^{3} \cdot \beta}{E} .
$$

\begin{tabular}{|c|c|c|c|c|c|}
\hline \multicolumn{2}{|c|}{ Brand of $\mathrm{AC}$} & AG-OV-1 & AG-5 & Purolat-Standart & $\mathrm{ABG}$ \\
\hline \multicolumn{2}{|c|}{ raw material } & coal & coal & anthracite & lignite \\
\hline \multicolumn{2}{|c|}{ carbonization /activation } & two-step & two-step & one-step & one-step \\
\hline \multicolumn{2}{|c|}{ granulation } & granular & granular & crushed & crushed \\
\hline \multicolumn{2}{|l|}{$\mathrm{S}_{\mathrm{BET}}, \mathrm{m}^{2} / \mathrm{g}$} & 682 & 925 & 311 & 412 \\
\hline \multicolumn{2}{|l|}{$\mathrm{V}_{\text {micro, }} \mathrm{cm}^{3} / \mathrm{g}$} & 0.218 & 0.465 & 0.07 & 0.02 \\
\hline \multicolumn{2}{|l|}{$\mathrm{V}_{\text {meso }}, \mathrm{cm}^{3} / \mathrm{g}$} & 0.241 & 0.135 & - & 0.24 \\
\hline \multirow{2}{*}{$\begin{array}{l}\mathrm{n}_{\text {surface group }} \\
\text { mmol-eq/g }\end{array}$} & acid & 0.32 & 0.36 & 0.24 & 0.19 \\
\hline & basic & 0.48 & 0.47 & 0.12 & 0.92 \\
\hline
\end{tabular}

\section{RESULTS AND DISCUSSION}

Obtained adsorption isotherms of benzene and pyridine on granular CA (Fig. 1) refer to the first I type (it is peculiar to microporous adsorbents) according to

Table 1. Characteristics of carbon adsorbents [7]

Carbon adsorbents were preliminarily heated at a temperature $110 \pm 5^{\circ} \mathrm{C}$ to remove all gases and water vapors absorbed at shelf time.

Adsorption of benzene and pyridine vapors was conducted by express-method [8] at $25 \pm 1{ }^{\circ} \mathrm{C}$, exposure time was 24 hours, error of relative pressure determination was not higher than $2 \%$ and error of adsorption amount was not higher than $6-9 \%$.

Basic parameters of the adsorption of organic substances were calculated with the use of linearized BET (1), Aranovich (2) and Dubinin-Astakhov (3) equations:

$$
\begin{aligned}
& Y_{B E T}=\frac{X}{a(1-X)}=\frac{1}{a_{m} C}+\frac{C-1}{a_{m} C} X, \\
& Y_{A P}=\frac{X}{a(1-X)^{0.5}}=\frac{1}{a_{m} C}+\frac{X}{a_{m} C},
\end{aligned}
$$

the Brunauer classification [1], the form of adsorption isotherms of pyridine by broken CA refers to the II type (mainly macroporous adsorbents).

Linearized forms of adsorption isotherms of the studied adsorbates on adsorbents AG-5 and ABG obtained with the usage of Eq. (1) and (2), correlation coefficients $\left(R^{2}\right)$, and linear dependence region are on Fig. 2.

Calculations showed (Fig. 1, Table 2) that relative pressure region, in which with high correlation degree experimental data are described by polymolecular adsorption models, is rather narrow and in this case benzene adsorption is better described by the Aranovich model and pyridine adsorption by the BET model (Fig. 1). Expected expansion of $\mathrm{P} / \mathrm{P}_{0}$, in which experimental data are described, in case of passing from the BET to the Aranovich model does not occur: for pyridine they almost coincide or become narrower, for benzene a considerable increase (up to $\mathrm{P} / \mathrm{P}_{0} \approx 0.62$ ) is observed only for Pulorat-Standart (Table 2). Similar 
behavior was observed in the case of adsorption of water vapors on soot with high oxygen surface compounds [9] and was explained by water clusters formation.

Low values of the coefficient $C$ (Table 2) show absence of precise localization of adsorbates on a carbon surface and difficulties of division of monolayer

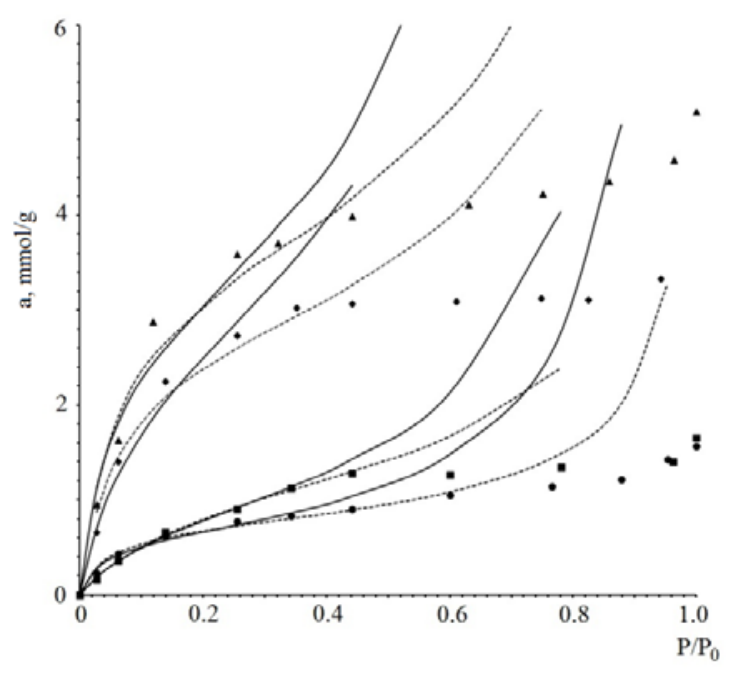

(a) and polymolecular layers formation processes [1]. Amount of calculated adsorption heat $(\Delta Q)$ allows to think that by adsorption of both benzene and pyridine additional specific sorbent-sorbate interaction is possible $(\pi-\pi-$ stacking and dipole-dipole for pyridine).

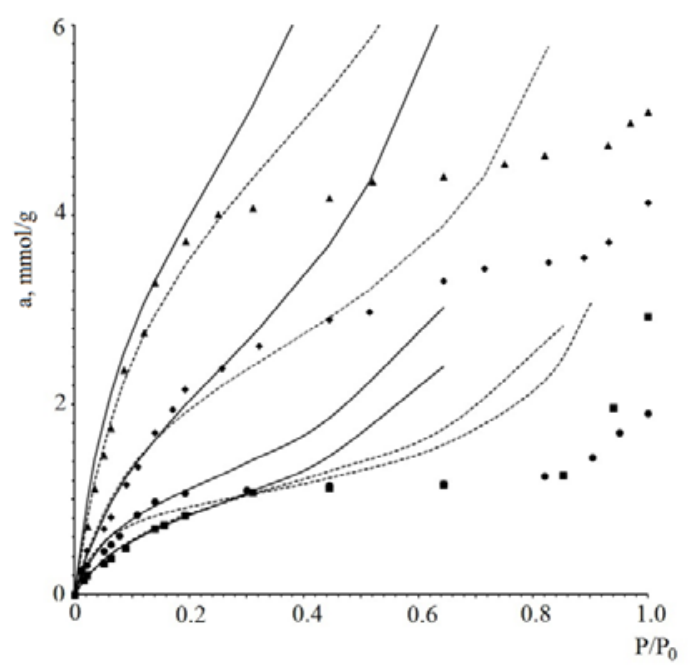

(b)

Fig. 1. Adsorption isotherms of benzene (a) and pyridine (b) vapors by carbon adsorbents AG-OV-1( $\bullet), A G-5$ ( $\mathbf{\Delta})$, Purolat-Standart $(\bullet)$ and ABG (घ): experimental (markers) and calculated by BET (solid line) and Aranovich (dotted line) equations.

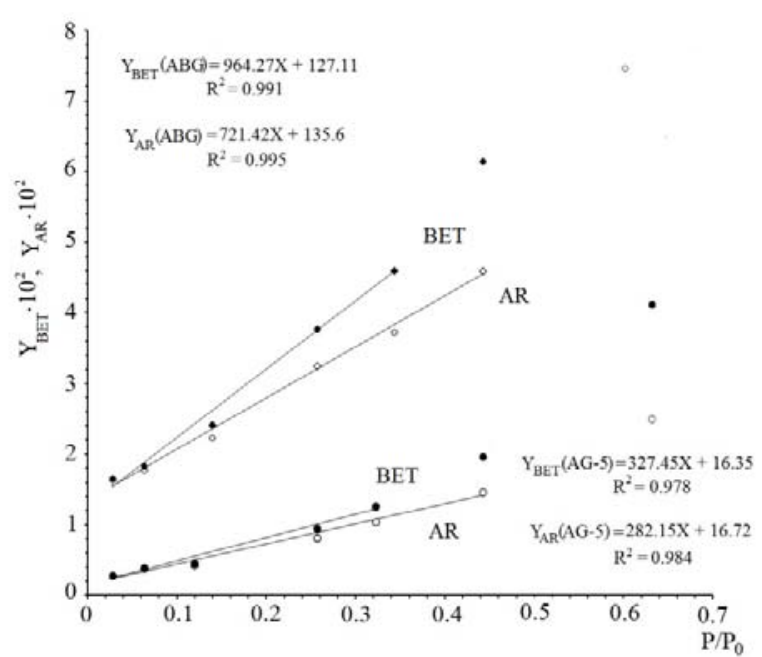

(a)

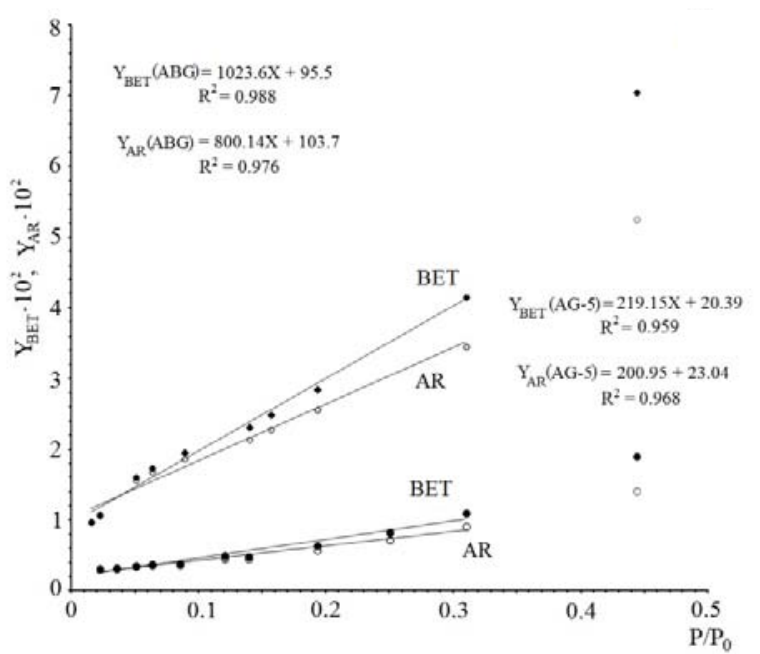

(b)

Fig. 2. Adsorption isotherms of benzene (a) and pyridine (b) vapors by carbon adsorbents AG-5 $(\bullet, \circ)$ and ABG $(\diamond, \diamond)$ in a linear form of BET and Aranovich equations.

Table 2. Parameters of benzene $(\mathrm{PhH})$ and pyridine (Py) adsorption calculated by BET and Aranovich equations

\begin{tabular}{|l|c|c|c|c|c|c|c|c|c|}
\hline \multirow{2}{*}{ Parameter } & \multirow{2}{*}{ Sorbate } & \multicolumn{2}{|c|}{ AG-OV-1 } & \multicolumn{2}{c|}{ AG-5 } & \multicolumn{2}{c|}{ Purolat-Standart } & \multicolumn{2}{c|}{ ABG } \\
\cline { 2 - 10 } & & BET & AR & BET & AR & BET & AR & BET & AR \\
\hline \multirow{2}{*}{$\mathrm{R}^{2}$} & $\mathrm{PhH}$ & 0.981 & 0.983 & 0.978 & 0.984 & 0.981 & 0.993 & 0.984 & 0.990 \\
\cline { 2 - 10 } & $\mathrm{Py}$ & 0.960 & 0.966 & 0.959 & 0.968 & 0.952 & 0.968 & 0.988 & 0.976 \\
\hline \multirow{2}{*}{ application up to } & $\mathrm{PhH}$ & 0.22 & 0.36 & 0.32 & 0.46 & 0.22 & 0.62 & 0.32 & 0.46 \\
\cline { 2 - 10 } & $\mathrm{Py}$ & 0.25 & 0.20 & 0.34 & 0.34 & 0.20 & 0.16 & 0.38 & 0.37 \\
\hline \multirow{2}{*}{$\mathrm{a}_{\mathrm{m}}, \mathrm{mmol} / \mathrm{g}$} & $\mathrm{PhH}$ & 2.66 & 2.77 & 2.91 & 3.54 & 0.61 & 0.74 & 0.92 & 1.39 \\
\cline { 2 - 11 } & $\mathrm{Py}$ & 2.29 & 2.73 & 4.12 & 4.98 & 1.10 & 1.16 & 0.89 & 1.25 \\
\hline \multirow{2}{*}{$\mathrm{C}$} & $\mathrm{PhH}$ & 12.03 & 16.70 & 21.02 & 16.88 & 27.52 & 22.71 & 8.59 & 5.32 \\
\cline { 2 - 11 } & $\mathrm{Py}$ & 9.39 & 8.57 & 13.72 & 8.72 & 15.98 & 16.73 & 11.72 & 7.71 \\
\hline \multirow{2}{*}{$\omega \mathrm{Q}, \mathrm{kJ} / \mathrm{mol}$} & $\mathrm{PhH}$ & 6.06 & 8.80 & 7.42 & 8.83 & 8.08 & 9.53 & 5.24 & 6.15 \\
\cline { 2 - 11 } & $\mathrm{Py}$ & 5.46 & 10.16 & 6.38 & 10.31 & 6.75 & 11.78 & 6.00 & 9.11 \\
\hline & $\mathrm{PhH}$ & 0.42 & 0.41 & 0.53 & 0.43 & 0.85 & 0.70 & 0.76 & 0.51 \\
\cline { 2 - 10 } & $\mathrm{Py}$ & 0.48 & 0.41 & 0.37 & 0.31 & 0.47 & 0.44 & 0.78 & 0.56 \\
\hline
\end{tabular}


Average area occupied by adsorbate molecule $\left(\omega_{\mathrm{m}}\right)$ in the case of adsorption on granular CA is comparable with elementary area of molecules $\left(0.40-0.44 \mathrm{~nm}^{2}\right.$ and $0.38-0.42$ for pyridine $[1,10])$, and it implies a closepacked molecule arrangement. A greater amount of $\omega_{\mathrm{m}}$ for benzene absorbed by broken $\mathrm{CA}$ and pyridine absorbed by $\mathrm{ABG}$ is probably connected with high contribution of specific interaction [1].

We should note a big difference between $a_{m}$ calculated by the Eq. (4) and (5) for AG-5 and ABG (Table 2). It can be explained by a higher surface heterogeneity of these sorbents and, as follows, by higher errors of monolayer capacity evaluation. The first of these CA is characterized by narrow micropores together with high oxygen surface compounds (prevalently carboxyl groups) [7], the second has the highest total content of polar surface groups (Table 1).

According to the calculation of average statistic thickness of an adsorption monolayer ( $t$-curve) with adsorption on granular CA benzene is oriented in parallel to the surface (layer thickness is $0.38-0.42 \mathrm{~nm}$, molecule thickness is $0.37 \mathrm{~nm}$ [1]), at the same time with adosption on broken CA orientation is random (layer thickness $0.46-0.68 \mathrm{~nm}$, molecule diameter

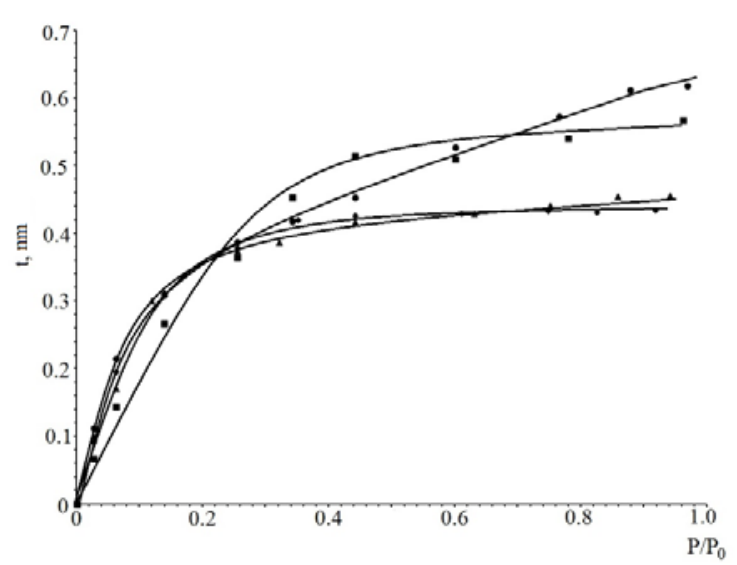

(a)
$0.71-0.75 \mathrm{~nm})$. Pyridine is oriented in parallel to the surface on all studied adsorbents (layer thickness is $0.36-0.42 \mathrm{~nm})$.

Limiting adsorption volume $\left(\mathrm{W}_{0}\right)$ of benzene and pyridine and also characteristic energy of their adsorption (E) on CA was calculated by the Eq. (3). In advance we evaluated exponent $\mathrm{n}$ in the DubininAstakhov equation. Obtained data and correlation coefficients $\left(\mathrm{R}^{2}\right)$ are presented in Table 3 .

Comparison of theoretically calculated isotherms with experimental data showed (Fig. 4, Table 3) that pyridine absorption by CA except for AG-5 is described by the equation with $n=2$ (takes the form of the Dubinin-Radushkevich equation). In the case of adsorption of both components by AG-5 and of pyridine by AG-OV-1 exponent $\mathrm{n}$ tends to 3, i.e. adsorbate molecule partially loses more than two degrees of freedom [11]. It is typical for adsorption in pores comparable to the diameter of an adsorbate molecule or in pores containing active polar centers $[5,11]$. Benzene adsorption on Purolat-Standart is better described by the equation where $n=1$ (corresponds to the adsorption in meso- and macropores) $[5,11]$.

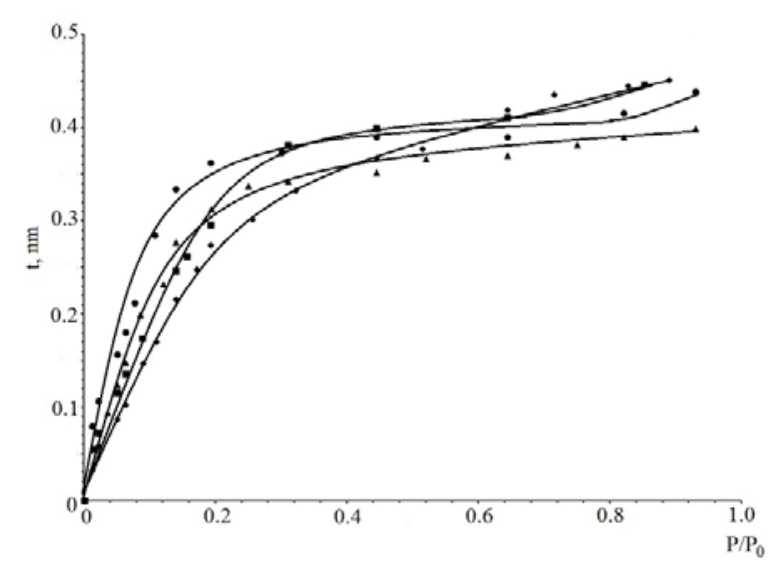

(b)

Fig. 3. t-curves of adsorption of benzene (a) and pyridine (b) vapors by carbon adsorbents AG-OV-1 ( $\bullet), A G-5$ ( $\Delta$ ), Purolat-Standart $(\bullet)$ and ABG (घ).

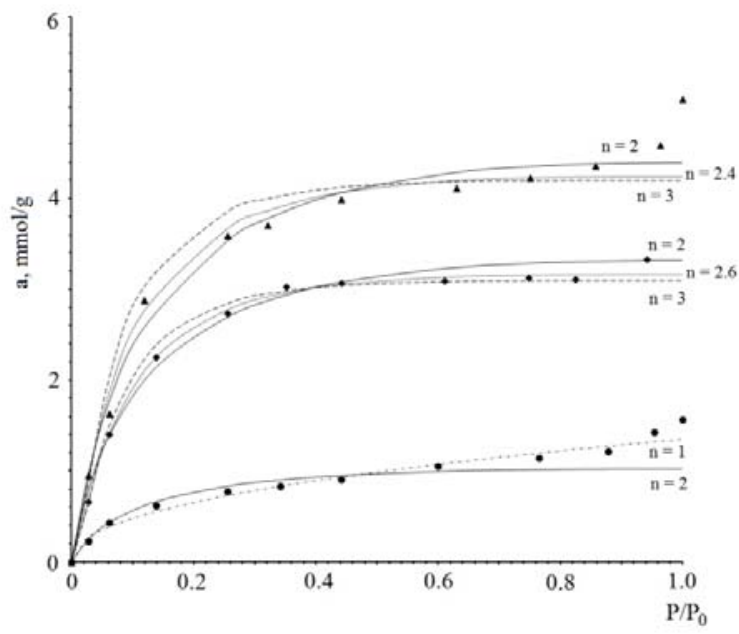

(a)

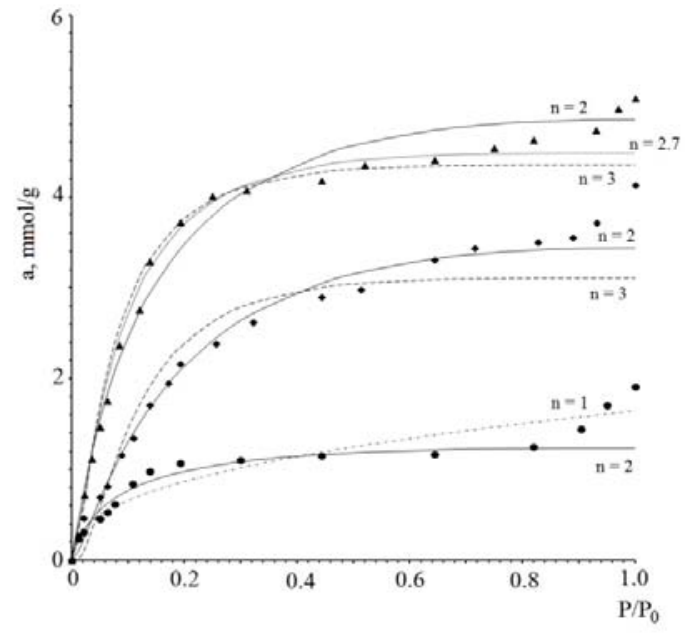

(b)

Fig. 4. Adsorption isotherms of benzene (a) and pyridine (b) vapors calculated by the Dubinin-Astakhov equation with different values of $n$; experimental points for carbon adsorbents AG-OV-1 ( $\bullet$ ), AG-5 (४) and Purolat-Standart $(\bullet)$ are on theoretical curves. 
Table 3. Parameters of benzene $(\mathrm{PhH})$ and Pyridine (Py) adsorption calculated by Dubinin-Astakhov equation

\begin{tabular}{|l|c|c|c|c|c|c|c|c|}
\hline \multicolumn{1}{|c|}{ Parameter } & \multicolumn{2}{c|}{ AG-OV-1 } & \multicolumn{2}{c|}{ AG-5 } & \multicolumn{2}{c|}{ Purolat-Standart } & \multicolumn{2}{c|}{ ABG } \\
\hline \multicolumn{1}{|c|}{ Sorbate } & PhH & Py & PhH & Py & PhH & Py & PhH & Py \\
\hline $\mathrm{R}^{2}$ & 0.999 & 0.995 & 0.986 & 0.988 & 0.970 & 0.970 & 0.981 & 0.978 \\
\hline $\mathrm{n}$ & 2.6 & 2.0 & 2.4 & 2.7 & 1.0 & 2.0 & 2.0 & 2.0 \\
\hline $\mathrm{W}_{0}, \mathrm{~cm}^{3} / \mathrm{g}$ & 0.28 & 0.28 & 0.38 & 0.36 & 0.12 & 0.10 & 0.11 & 0.10 \\
\hline $\mathrm{E}, \mathrm{kJ} / \mathrm{mole}$ & 5.55 & 5.67 & 7.32 & 7.18 & 5.39 & 8.09 & 6.02 & 6.98 \\
\hline$\chi, \mathrm{nm}$ & 2.16 & 2.39 & 1.64 & 1.79 & 2.23 & 1.68 & 1.99 & 1.94 \\
\hline
\end{tabular}

Comparison of calculated value $\mathrm{W}_{0}$ (Table 3 ) with value of CA pores (Table 1) showed that both components, when absorbed on AG-OV-1, fill available in size micro- and mesopores $\left(\mathrm{W}_{0}>\mathrm{V}_{\text {micro }}\right)$, and on AG-5 they fill available micropores $\left(\mathrm{W}_{0}<\mathrm{V}_{\text {micro }}\right)$. In the case of broken CA we can only formally talk about volume filling of available microand mesopores because Purolat-Standart is mainly a macroporous adsorbent and ABG has a small amount of micropores. Values of adsorption characteristic energy and half-width of slit-like pores $(\chi)$ confirm assumptions on adsorbate localization in available in size micro- and mesopores.

\section{CONCLUSION}

Conducted research showed that benzene and pyridine adsorption on studied adsorbents is described by the equations of polymolecular adsorption in a narrow range of relative pressure and in this case it is characterized by low energetic constant value ( $\mathrm{C}$ is not higher than 28). It does not enable us to determine accurately characteristics of a formed monolayer for adsorbents with micropores (granular) and meso- and macropores (crushed). In the latter case such behavior is explained by the surface heterogeneity because of high oxygen surface compounds. As a result, pyridine and benzene adsorption is a complete process of attraction - repulsion between active centers of adsorbate molecules ( $\pi$-electron aromatic system and an unshared electron pair of nitrogen for pyridine) and adsorbent surface groups. Random orientation of benzene molecules when absorbed by broken CA and difference in adsorption behavior of benzene and pyridine (molecules are of similar size) when monolayer is filled are also connected with it.

Benzene and pyridine volume filling happens not only in micropores but also in mesopores. In this case a big amount of oxygen surface compounds (and possibility of the specific sorbent-sorbate interaction) is realized in increase of $\mathrm{n}$ from 2 to 3 in the DubininAstakhov equation when both components are absorbed by AG-5. Proximity of calculated amount of benzene and pyridine limiting adsorption volume presupposes similar mechanism of pore filling with these components. Differences in adsorption behavior of these components at a time of monolayer filling are probably connected with peculiarities of molecule structure of pyridine which in comparison with benzene has additional potential adsorption center, i.e. an unshared electron pair of nitrogen.

\section{REFERENCES}

1. Gregg S. J., Sing K. S. W. Adsorption, Surface Area and Porosity. 2nd ed. New York, Academic Press, 1982. 304 p.

2. Karnaukhov A.P. Adsorption. Tekstura dispersnykh i poristykh materialov [The texture of dispersed and porous materials]. Novosibirsk, Science. Sib. Enterprise RAS, 1999. 470 p.

3. Aranovich G. L. New Polymolecular adsorption isotherm. J. colloid and interface science, 1991, vol. 141, no. 1, pp. 30-43.

4. Kamalyan O.A., Stepanyan A.V., Sargsyan A.V., Sarkezian V.A., Kamalyan T.O. Sravnitel'nyy analiz nekotorykh uravneniy adsorbtsii. - Khimiya, fizika i tekhnologiya poverkhnosti [Comparative analysis of some adsorption equations]. Khimiya, fizika i tekhnologiya poverkhnosti [Chemistry, physics and surface technology], 2011, vol. 2, no. 3, pp. 262-265.

5. Dubinin M.M. Poverkhnost' i poristost' adsorbentov [Surface and porosity of the adsorbent]. Uspekhi khimii [Russian Chemical], 1982, vol. 7, pp. 1065-1074.

6. Weissberger A., Proskauer E.S., Riddick J.A., Toops E.E. Organic solvents. Physical properties and methods of purifications. New York, Interscience Publishers Inc, 1955. 520 p.

7. Krasnova T.A., Belyaeva O.V., Golubeva N.S. Ochistka promyshlennykh stochnykh vod ot azotsoderzhashchikh organicheskikh soedineniy [Treatment of industrial waste water from the nitrogen-containing organic compounds]. Kemerovo, Ed. KemTIPP, 2011. 146 p.

8. Andriyantseva S.A., Bondarenko A.V., Petukhova G.A. Eksperes - metod issledovaniya izotermy adsorbtsii benzola uglerodnymi gidrofobnymi materialami [Express - method of investigating the adsorption isotherms of benzene carbon hydrophobic materials]. Sorbtsionnye i khromatograficheskie protsessy [Absorbent and chromatographic processes], 2012, vol. 12, no. 1, pp. 114-118.

9. Popovicheva O.B., Persiantseva N.M., Tishkova V, Shonija N.K., and Zubareva N.A. Quantification of water uptake by soot particles. Environ. Res. Lett., 2008, vol. 3, no. 12, pp. 30-43. doi:10.1088/1748-9326/3/2/025009

10. Kel'tsev N.V. Osnovy adsorbtsionnoy tekhniki. 2-e izd. [Fundamentals of adsorption technology. 2nd ed.]. Moscow: Chemistry, 1984, pp. 40-46.

11. Koganovskii A.M., Klimenko N.A., Levchenko T.M., Marutovskii R.M., Roda I.G. Ochistka i ispol'zovanie stochnykh vod v promyshlennom vodosnabzhenii [Treatment and use of wastewater in industrial water supply]. Moscow: Chemistry, 1983, pp. 76-78.

\section{Oksana V. Belyaeva}

Cand.Sci.(Eng.), Associate Professor of the Department of Analytical Chemistry and Ecology, Kemerovo Institute of Food Science and Technology (University), Kemerovo, Russian Federation.

\section{Tamara A. Krasnova}

Dr.Sci.(Eng.), Professor, Head of the Department of Analytical Chemistry and Ecology, Kemerovo Institute of Food Science and Technology (University), Kemerovo, Russian Federation. 